\title{
Is the Export-led Growth Hypothesis Enough to Account for China's Growth?
}

\author{
María Jesús Herrerias, Vicente Orts
}

\begin{abstract}
The purpose of the present paper is to analyze whether the expansion of the Chinese economy is based on an export-led growth effect or, on the contrary, Chinese development between 1964 and 2004 was driven by investment. However, since we know the relevance of the real exchange rate in an open economy such as China, we also investigate the relationship between the real exchange rate and growth. Our empirical evidence shows that both investment and exports are relevant factors in the Chinese economy. These results are consistent with the idea that not only are exports the main engine of growth, as other papers have argued, but it also seems that the significant investment effort has played a key role in accounting for China's growth in the last few decades. Furthermore, unlike previous works, we find that the real exchange rate has been used as an additional economic policy to encourage output in the long run.
\end{abstract}

Key words investment, labor productivity, openness, output

JEL codes F43, O40, O47, O53

\section{Introduction}

The Chinese economy has been undergoing a spectacular process of growth for almost 4 decades.

China's GDP showed an average growth rate of around 8 percent over the period 1963-1978, in spite of the negative effects derived from the Great Leap Forward and the Cultural Revolution. Furthermore, this growth accelerated even further from the end of the 1970s until 2004, when the annual average growth rate reached more than 9 percent, and exceeded 10 percent in 2005 . This

\footnotetext{
${ }^{*}$ Vicente Orts, Professor, Department of Economics and Institut of International Economics, Universitat Jaume I, Castellón, Spain. Email: orts@eco.uji.es. María Jesús Herrerias, Associate Researcher, Department of Economics, Universitat Jaume I, Castellón, Spain. Email: herreria@eco.uji.es. The authors gratefully acknowledge financial support from the Spanish Ministry of Science and Innovation (project ECO2008-06057/ECON) and the Generalitat Valenciana (BFPI06/442 and Prometeo/2009/068).
} 
evolution, which has no parallel with other economies today or probably with any others in the past, has helped increase the Chinese contribution to the world GDP. Thus, the percentage of the Chinese contribution to the world GDP rose from less than 1 percent at the beginning of the 1960 s to 5 percent in the middle of the 2000s.

Much of the empirical literature has attributed this sharp economic growth to openness and especially to the expansion of exports. Indeed, it is well known that in 1978 China embarked upon an ambitious program of economic reforms. These reforms (which include the progressive adoption of market-oriented and open-door strategies for development that culminated in 2001 with China's adhesion to the WTO) have led to an impressive export performance, with Chinese participation in the world export markets increasing from negligible values to more than 7 percent in 2005 . However, this explanation cannot account for the significant growth this country underwent before 1978. Instead, like other planned economies, its growth in this period probably relied on high investment rates. But since 1978, instead of decreasing, the investment-to-GDP ratios have in fact increased even more. Therefore, in the 1960s the average investment rate was 20 percent and its trend has been to increase steadily ever since, reaching values of over 30 percent in the 1990s and over 40 percent in 2004. Hence, the concurrence of high investment rates and fast expansion of exports sparked the debate about their role in China's economic growth. The core issue is probably a reappraisal of the controversy that appeared in the mid-1990s in relation to the sources of economic growth in high-performing Asian economies (Young, 1992; Pack and Page, 1994). As Paul Krugman wrote in 1994 (Krugman, 1994, p. 70), “Asian growth, ... seems to be driven by extraordinary growth in inputs like work and capital rather than by gains in efficiency." Therefore, the experience of the "Asian tigers" showed a possible alternative scenario by which the mechanisms for growth differed from those previously considered (trade and especially export expansion). Rodrik (1995) even argued that the rapid growth of these economies was caused by investment booms, the expansion of trade being a consequence of this process. 
The question would be of no greater significance if it were not for the foreseeable differences in relation to the long-run sustainability of growth and its implications on economic policy. Have Chinese policies aimed at promoting domestic saving at the expense of consumption contributed from the point of view of long-run growth? Has capital accumulation given rise to permanent increases in productivity, that is, improved workers' efficiency? Is the adoption or the maintenance of almost mercantilist export programs really a suitable strategy in China? The role played by capital accumulation and exports on economic growth thus continues to be one of the missing pieces preventing us from understanding recent Chinese economic development. Therefore, the doubt arises as to whether the sharp economic growth that the Chinese economy has experienced is another case of export-led growth due to the open-door policy or whether, on the contrary, this growth has been caused by high domestic saving and investment rates (and the consequent capital accumulation), which is known as the investment-led growth effect in the empirical literature. This proves to be an interesting question to be investigated in this work from both an academic point of view and a perspective that is strictly related to the evaluation and decision-making of economic policy.

However, the investment or open-door policy in China cannot be understood without taking the exchange rate policy carried out by the Chinese government into account in the analysis. In this regard, recent empirical evidence suggests that the real exchange rate plays an important role in influencing output in the long run (Levi-Yeyati and Sturzenegger, 2007; Gala, 2008; Rodrik, 2008). The case of China, along with the experiences of other developing countries that often maintain a competitive exchange rate, has sparked a great deal of interest in the relationship between the real exchange rate and output, due to the fact that an additional tool has also been used to enhance growth. And this is the mechanism through which the increase in domestic savings and investment rates operates (Levi-Yeyati and Sturzenegger, 2007) rather than through export expansion, as suggested by Rodrik (2008). However, in spite of these arguments, little work has been carried out 
on the case of China. Therefore, in the present paper, we are going to look for the three features that were stressed in China between 1964 and 2004. Moreover, unlike other studies such as Yu (1998) and Kwan et al. (1999), first we consider factors such as research and development (R\&D) expenditure as determinants of economic growth in China, and second we improve the empirical specification significantly. In particular, Yu (1998) employed the Engle and Granger two-step estimator over the period 1980-1990, and found that exports and investment explained output growth. In a time series approach using data from 1952 to 1993, Kwan et al. (1999) estimated equation by equation and found empirical evidence of the contribution of investment and exports to growth, exports being consistent with large increases in investment. However, neither of these papers takes the endogeneity problem into account in the analysis, since a joint estimation of the variables in growth empirics is very demanding.

In the present paper we use the cointegrated VAR model as our empirical framework. This methodology enables us to perform a joint modeling within a context in which our variables are closely related to each other and there may be problems of endogeneity. Furthermore, in order to consider the existence of structural changes in our relations and to guarantee the stability of the parameters, we allowed structural breaks in the estimated models. Moreover, we also allowed for multiple long-run relationships and we explicitly tested the long-run weak exogeneity to clarify the direction of the causality between the variables of interest, both in the short and the long run.

The paper is arranged as follows. In the next section we review the literature to see how exports and capital accumulation encourage output and productivity. In Section III, we define the variables and present the econometric methodology. The empirical analysis is included in Section IV. Finally, some concluding comments are provided in the fifth section. 


\section{Literature Review}

The conventional Solow-Saw textbook growth model and endogenous growth models both highlighted the importance of capital accumulation in the process of growth. However, there is little agreement on the long-run effect of investment on growth. The first of these models suggests that capital accumulation plays a minor role in long-run economic growth. Of course, these models show that countries which invest more also tend to grow more. However, this effect seems to be transitory and could disappear in the absence of other factors that stimulate steady-state growth. From this perspective, investment could not be considered a source of sustained economic growth. This belief is also supported by R\&D-based endogenous growth models (Romer, 1986; Grossman and Helpman, 1991). However, De Long and Summers (1992) argue that investment in equipment is apparently associated with higher growth, due to the embodied technological progress, and the positive role of government investment in infrastructures in improving economic activity and productivity is well known (Aschauer, 1989). These findings are more consistent with the main implications of other types of endogenous growth models, such as the AK or Schumpeterian models (Rebelo, 1991; Howitt, 2000). Furthermore, in this kind of models, "capital and knowledge are two state variables determining the level of output at any point of time" and "capital accumulation and innovation should be complementary processes, both playing a critical role" (Howitt and Aghion, 1998, p. 112). Therefore, both investments in equipment and $R \& D$ expenditure can interact to reinforce this relationship.

Therefore, from a theoretical and empirical point of view, capital accumulation is not free of a certain amount of ambiguity as regards its relationship with the GDP or labor productivity. For example, Jones (1995) concludes that AK growth models do not provide a good description of growth in 15 selected OECD countries, while Blomstrom et al. (1996) found that causality runs from economic growth to investment. Nevertheless, the opposite view may also be found in the 
empirical literature. For example, Bond et al. (2004) recently found evidence that an increase in investment as a share of the GDP predicts a higher rate of growth of output per worker.

The literature contains little empirical evidence of the investment-led growth effect in China. However, any evidence to this effect does seem to recognize that capital accumulation has played an important role in the process of economic growth (Kwan et al., 1999). ${ }^{1}$ For example, Chow (1993) emphasized the role of capital accumulation as the main source of Chinese economic growth from the 1950s until the end of the 1980s. Nevertheless, there was no evidence of technological progress during this period. Yusuf (1994), however, argued that not only was capital accumulation an important determinant of economic growth, but that technological progress also played a significant role from 1978 to 1993 . Further still, some authors, like $\mathrm{Hu}$ and Khan (1996) or Caruso (2002), argued that although the growth in productivity rose sharply during the early years of the reform, during the pre-reform period it was also positive, in contrast to Chow's view. Finally, unlike previous studies, Qin et al. (2005) recently found some evidence that output drives investment in the Chinese economy.

On the other hand, openness, especially the expansion of exports, has also been considered to be one of the key factors to promote economic growth in developed and developing countries (Lopez, 2005). Among the channels identified in the literature as potential generators of positive effects on output and productivity, the most immediate is the possibility that exposure to trade will induce a self-selection of the firms (Melitz, 2003), the most productive being the ones that finally become exporters and therefore have a positive effect on the aggregate productivity. In addition, economies of scale, more efficient management and organization styles, and the existence of positive spillovers are found to be suitable channels through which exports influence economic growth (Feder, 1983; Helpman and Krugman, 1985). Finally, the exporting activity allows foreign

\footnotetext{
${ }^{1}$ Kwan et al. (1999) found empirical evidence that investment had a positive influence on growth during the period 1953-1993.
} 
exchange constraints to be relaxed, thus permitting increased imports of capital and intermediate goods (Esfahani, 1991).

Nevertheless, despite these arguments, there is some skepticism about the ability of openness to explain success in foreign markets and productivity gains, or about exporting firms' being more productive than non-exporters (Rodriguez and Rodrik, 2001). We even found evidence for the existence of a growth-driven exports hypothesis, according to which countries with higher incomes engage in more trade (Helpman, 1988). In fact, the endogeneity problem has been a recurrent aspect in the empirical literature on openness and growth (Frankel and Romer, 1999; Noguer and Siscart, $2005)$ and there are no conclusive results, especially in the time series analysis.

The evidence found in the Chinese economy is in agreement with the rest of the empirical literature. On the one hand, Shan and Sun (1998) offer a wide selection of empirical studies on the export-led growth hypothesis, and all papers seem to support the hypothesis. However, their results indicate that bidirectional causality exists between exports and output in China. The positive effect of exports on output is also found in Liu Xiaming et al. (1997), Liu Xiaohui et al. ( 2002), Lin (1999), Jin (2004) and Yao (2006) but with different specifications. ${ }^{2}$ Notice that in many cases these results are found because exports are considered to be an endogenous variable without testing their weak exogeneity. In the present paper, suitable tests will be used to provide evidence that, for the case of China, exports become a weakly exogenous variable in the long run. This implies that exports may influence output, but it is not possible to find the reverse causation in the long run. On the other hand, and contrary to the general perception, in a recent paper Hsiao and Hsiao (2006) find that exports are not the cause of China's GDP. Thus, the current empirical literature on the role that exports play in Chinese economic development seems inconclusive.

Regardless of the controversial aspect of the direction in which causality runs between investment and output, investment-led growth in China should be reconciled with the spectacular

\footnotetext{
${ }^{2}$ See also Rodrik (2006) for evidence on the structure of Chinese exports as a key role in China's growth.
} 
growth of Chinese exports. This possibility was underlined by Rodrik (1995) when explaining the economic growths of Korea and Taiwan in the 1960s. According to Rodrik, the outward orientation of these economies was more the result of the investment boom than the consequence of an exportled growth effect. The increase in exports was the result of export-oriented policies that enabled the increase in demand for imported capital goods (a consequence of the investment boom) to be met. However, as Baldwin and Seghezza (1996) argue, the opposite point of view is also feasible. According to these authors, trade-induced investment-led growth could have taken place and, in line with our results, there is evidence that both exports and investment are determinants that boost output growth (Yu, 1998; Kwan et al., 1999).

Related to this debate, it is a fact that the success or failure of export-led growth strategies depends on many factors and domestic economic policies. One of these is the role of the real exchange rate. Recent empirical evidence indicates that the real exchange rate has been used as a tool to promote output in the long run, especially in developing countries (Gala, 2008; Rodrik, 2008). While Levi-Yeyati and Sturzenegger (2007) argue that the long-run effect of the real exchange rate seems to work through greater investment and savings, Rodrik (2008) suggests the size of the tradable sector as the main channel in which to find this effect. This issue is important for the Chinese economy, since the government has been interested in maintaining a competitive exchange rate for a long time and this policy has been carried out simultaneously with aggressive promotion of exports and investment that has presumably helped to achieve rapid economic growth. However, little effort has been made to examine all these factors in a unified framework. In this paper, unlike other studies that consider exports to be the main engine of growth, we provide an alternative perspective of the drivers of China's growth by considering additional growth factors other than exports. 


\section{Econometric Methodology and Data}

Assuming a Cobb-Douglas production function, where output is a constant returns function of capital and labor, that is $Y=A K^{\alpha} L^{1-\alpha}$, the standard Solow-Swan model of growth found that a permanent increase in investment or in the level of exogenous technological progress $(A)$ predicts a higher level of output per worker, and this is our theoretical point of departure. However, we can think that within a context of more recent versions of endogenous growth models, there are a variety of factors that could account for the improvement of technological progress, understood in a broad sense. In fact, in the literature review presented by Grossman and Helpman (1991), they found at least ten potential determinants of long-run growth, including investment, openness, R\&D expenditure, and others like institutions, property rights, and so forth. In the present paper, due to the characteristics of the Chinese economy as well as the data that is currently available, we focus first on the effects of exports and investment on GDP and labor productivity, and second we analyze additional factors of growth like R\&D expenditure, or improved competitiveness, as recently emphasized by several authors like Rodrik (2008) and Gala (2008).

Therefore, more specifically our empirical analysis basically uses annual data for China for the period 1964-2004 provided by the National Bureau of Statistics of China. ${ }^{3}$ Our dataset consists of the GDP (Igdp), labor productivity - output per worker - (Iprod), investment (linv), exports in FOB terms (lexp), R\&D expenditure (Ird) of the Chinese economy, the real exchange rate (Irer), and the US GDP (Igdpusa). ${ }^{4,5}$

\footnotetext{
${ }^{3}$ China Compendium of Statistics 1949-2004, published byNational Bureau of Statistics of China (NBS). Base year 1952=100. We have used the original base year derived from the NBS. Moreover, although Chinese National Accounts started in 1952, we moved the beginning of the effective sample to 1964. This change was due to the difficulty involved in performing a sufficiently homogenous treatment over such a turbulent period as the one between 1958 and 1962, with the Great Leap Forward and the consequent economic collapse that produced abnormally low values of macroeconomic aggregates for the period 1961-1963 (Chow, 1993).

${ }^{4}$ This variable was introduced into the model as a control variable. Justification for including this kind of control variable in a similar context to this paper can be seen in Marin (1992). Morever, US GDP is usually employed as a reference country representing world activity. Data from the USA were taken from the Bureau of Labor Statistics and Bureau of Economic Analysis.
} 
The empirical strategy begins with an analysis of the stationary properties of our variables, which can be seen in Table 1. It is possible to see from the unit root test (Phillips Perron and Augmented Dickey Fuller) that all the variables that we considered are $I(1)$ in levels and we reject the possibility of them being $I(2)$.

Table 1. Unit Root Tests

\begin{tabular}{lcccccc}
\hline \multicolumn{2}{c}{ Model 1 (trend \& constant) } & \multicolumn{2}{c}{ Model 2 (constant) } & \multicolumn{2}{c}{ Model 3 (none) } \\
\hline \multicolumn{2}{c}{ Phillips-Perron } & \multicolumn{2}{c}{ Phillips-Perron } & \multicolumn{2}{c}{ Phillips-Perron } \\
\hline Variable & Levels & Difference & Levels & Difference & Levels & Difference \\
\hline lgdp & -1.75 & $-5.04^{*}$ & 0.73 & $-4.77^{*}$ & 22.38 & $-2.61^{* *}$ \\
lprod & -0.23 & $-6.47^{*}$ & 5.47 & $-4.01^{*}$ & $-3.11^{*}$ & $-3.52^{*}$ \\
lexp & -2.31 & $-5.64^{*}$ & 1.34 & $-5.41^{*}$ & 6.83 & $-2.91^{*}$ \\
lrer & -1.63 & $-5.43^{*}$ & -1.01 & $-5.47^{*}$ & 1.95 & $-4.94^{*}$ \\
lgdpusa & $-4.13^{* *}$ & $-4.89^{*}$ & -1.76 & $-4.81^{*}$ & 10.50 & $-1.91^{* *}$ \\
lrd & -2.39 & $-6.40^{*}$ & -0.19 & $-5.59^{*}$ & 5.25 & $-4.12^{*}$ \\
linv & -3.14 & $-5.90^{*}$ & -0.52 & $-5.82^{*}$ & 10.30 & $-3.46^{*}$ \\
\hline
\end{tabular}

\begin{tabular}{lcccccc}
\multicolumn{2}{c}{ Model 1 (trend \& constant) } & \multicolumn{2}{c}{ Model 2 (constant) } & \multicolumn{2}{c}{ Model 3 (none) } \\
\hline \multicolumn{2}{c}{ Augmented Dickey Fuller } & Augmented Dickey Fuller & Augmented Dickey Fuller \\
\hline Variable & Levels & Difference & Levels & Difference & Levels & Difference \\
\hline lgdp & -1.73 & $-4.44^{*}$ & 0.25 & $-4.48^{*}$ & 11.01 & $-2.22^{* *}$ \\
lprod & -0.56 & $-4.62^{*}$ & 2.30 & $-5.35^{*}$ & $-2.69^{*}$ & $-3.48^{*}$ \\
lexp & -2.35 & $-5.67^{*}$ & 1.36 & $-5.40^{*}$ & 7.15 & $-3.04 *$ \\
lrer & -1.46 & $-5.50^{*}$ & -1.01 & $-5.53^{*}$ & 2.09 & $-4.93^{*}$ \\
lgdpusa & $-4.93^{*}$ & $-4.90^{*}$ & -1.39 & $-4.37^{*}$ & 10.26 & $-2.17^{* *}$ \\
lrd & -2.38 & $-4.60^{*}$ & -0.43 & -4.63 & 3.05 & $-4.14^{*}$ \\
linv & $-4.88^{*}$ & $-4.81^{*}$ & -0.45 & $-4.88^{*}$ & 5.87 & $-3.26^{*}$ \\
\hline
\end{tabular}

Note: * Rejection of the null hypothesis at 1 percent; ** Rejection of the null hypothesis at 5 percent; *** Rejection of the null hypothesis at 10 percent.

The methodology that we used is the cointegrated vector autoregressive (VAR) model proposed by Johansen (1995) and Johansen and Juselius (1994). ${ }^{6}$ We start the analysis with a broad general specification in which certain restrictions will be imposed until the most irreducible form is

\footnotetext{
${ }^{5}$ All variables are in logs and real terms, and have been deflated by the GDP deflator. The real exchange rate was calculated using the nominal exchange rate between the Chinese currency and the US dollar (Renminbi/\$) and the consumer price indices (CPIs).

${ }^{6}$ This methodology is based on the principle of "general to specific" discussed in Hendry and Mizon (1993).
} 
reached. ${ }^{7}$ More specifically, we start with an unrestricted VAR model, with a restricted linear trend in the cointegration space, and with an unrestricted constant $(\mu)$ of dimension $r \times 1$ :

$$
\begin{gathered}
\Delta X_{t}=\alpha \widetilde{\beta}_{i}^{\prime}\left(\begin{array}{c}
X \\
Z \\
t \\
D_{s}
\end{array}\right)_{t-1}^{k-1}+\sum_{i=1}^{k} \Gamma_{i} \Delta X_{t-i}+\omega \Delta Z_{t}+\sum_{i=1}^{k-1} \omega_{i} \Delta Z_{t-i}+\theta \Delta D_{s t}+\sum_{i=1}^{k-1} \theta_{i} \Delta D_{s t-i}+\varphi D_{t}+\mu+\varepsilon_{t} \\
\varepsilon_{t} \sim \operatorname{NIID}(0, \Omega) \quad t=1 \ldots T
\end{gathered}
$$

where $\alpha \beta \square_{i}$ are the coefficients of the long-run matrix, $\alpha$ gives the direction and speed of adjustment toward equilibrium, and $\beta \square_{i}$ are the coefficients of the cointegrated vectors; $X$ is the matrix of endogenous variables in the model, $Z$ is the matrix of weakly exogenous variables, $t$ is the linear trend restricted to the cointegration space, and $D_{s t}$ is the matrix of the level-shift dummy; $\Gamma_{i}$ is the unrestricted matrix of the coefficients in the short run and of dimension $p x p$, while $\omega_{i}$ and $\theta_{i}$ are the coefficients of the variables that have been considered prior to analyzing the weakly exogenous variables $\left(Z_{t}\right)$ and the level-shift dummy $\left(D_{s t}\right),{ }^{8}$ respectively. Finally, the term $\left(\varphi D_{t}\right)$ contains a vector of unrestricted dummy variables and their corresponding coefficients. ${ }^{9,10}$ In addition, we assumed that the error term, $\varepsilon_{t}$, is an i.i.d. Gaussian sequence $N(0, \Omega)$ and the initial values, $\mathrm{X}_{-\mathrm{k}+1}, \ldots \mathrm{X}_{0}$, are fixed.

\footnotetext{
${ }^{7}$ Applications of cointegration techniques for the case of China can be found in Chen et al. (2009), among others.

${ }^{8}$ We have included two level-shift dummies restricted to the cointegration spaces in $1978\left(D_{\mathrm{s} 78}\right)$ and in 1994 $\left(D_{\mathrm{s} 94}\right)$ in accordance with the set of stability tests.

${ }^{9}$ The dummy $\mathrm{D}_{89 \mathrm{p}}$ attempts to capture the political instabilities and economic restrictions in 1989 (restrictive fiscal and monetary policies were introduced by the Chinese government at the end of 1988 to stem sharply rising inflation, the contractive effects of which coincided with the events that took place in Tiananmen Square).

${ }^{10}$ The criterion to include a dummy was $\left(\left|\hat{\varepsilon}_{1, t}\right|>3.3 \hat{\sigma}_{\varepsilon}\right)$. For futher details of the impact of deterministic components in the VAR Model, see Juselius (2007).
} 


\section{Empirical Analysis}

\section{Productivity Model}

Initially, the endogenous variables considered in the model presented in this section are labor productivity, ${ }^{11}$ investment, exports, real exchange rate, and R\&D expenditure. The US activity level was included to capture foreign influence on the Chinese economy, and it was considered a weakly exogenous variable right from the beginning. Starting from this five-equation system, the exogeneity test suggested that exports could be managed as an exogenous variable with a $p$-value of 0.90. Under this new specification with four endogenous variables (productivity, investment, real exchange rate, and R\&D expenditure) and two exogenous variables (exports and US activity), the exogeneity test was applied to show that $R \& D$ expenditure can also be considered an exogenous variable with a $p$-value of 0.73 . Finally, the determination of the number of lags, according to the criterion of Hannan and Quinn, indicates that two lags are enough to capture the dynamic effects of the model and to avoid autocorrelation problems. ${ }^{12}$ In short, the definitive specification that we have considered is a VAR (2) model with three endogenous variables (productivity, investment, and real exchange rate) and three exogenous variables (exports, R\&D expenditure, and US activity), with their corresponding deterministic components. ${ }^{13} \mathrm{We}$ made a battery of misspecification tests for the residuals of the model, where neither autocorrelation nor normality problems existed. ${ }^{14}$

Based on the statistical model, we can obtain the number of long-run relationships $(r)$, and the number of common trends $(p-r)$ by using the LR test. Table 2 shows the trace test, where everything seems to indicate that two long-run relationships $(r=2)$ exist in our model, as well as a common trend. In addition, the inverse root of the characteristic polynomial for this rank is $0.80-$ less than unity - which therefore shows that our model is stationary.

\footnotetext{
${ }^{11}$ In this model productivity was corrected by applying the methodology suggested by Nielsen (2004).

12 These tests are available upon request from the authors.

${ }^{13}$ See Juselius (2007) for the description of the specification process.

${ }^{14}$ Available upon request for both models.
} 
Table 2. Determination of the Rank Test in the Productivity model

\begin{tabular}{cccccccc}
\hline $\mathrm{p}-\mathrm{r}$ & $\mathrm{r}$ & Eigenvalue & Trace & Trace* & $95 \%$ & $\mathrm{p}$-value & p-value* \\
\hline 3 & 0 & 0.77 & 117.85 & 100.96 & 77.10 & 0.000 & 0.000 \\
2 & 1 & 0.59 & 56.11 & 49.36 & 49.6 & 0.011 & 0.052 \\
1 & 2 & 0.37 & 19.09 & 16.55 & 25.86 & $\mathbf{0 . 2 5 4}$ & $\mathbf{0 . 4 1 5}$ \\
\hline
\end{tabular}

Note: *corresponds to the trace test with Bartlett's correction. The asymptotic distributions have been simulated for the current deterministic specifications

The following cointegration vectors can be found in the selected model. They are expressed as error correction mechanisms (t-values in brackets):

$$
\begin{array}{r}
e c m_{1}=\text { Iprod }-0.16 l i n v-0.29 / \exp -0.17 D_{s 94} \\
{[-4.47] \quad[-11.77] \quad[-5.97]} \\
e c m_{2}=l i n v-0.31 / r d+0.20 D_{s 78}-0.08 t \\
{[-5.73][-6.99] \quad[-24.73]}
\end{array}
$$

The first relationship corresponding to (2) describes how exports and investment both account for the level of productivity in the long run. On the other hand, the second relationship (3) shows that $R \& D$ expenditure favors an increase in investment. The coefficients associated with the two relationships are statistically significant and show the expected signs. The restrictions imposed on both cointegration relationships were accepted with a p-value of 0.175 . The coefficients of adjustment toward equilibrium are statistically significant and negative, and take a value of -0.36 $(-5.55)$ for the first cointegrated vector and $-0.64(-5.86)$ for the second. Although complete parameter constancy is difficult to guarantee in a period of such important economic changes, the reduced-form model is stable in the forward and backward analysis. ${ }^{15}$ In this sense, our estimates should be considered as average effects throughout the period analyzed.

Our findings are consistent with an export-led productivity growth effect. The first long-run relation in (2) shows a positive relationship between productivity and exports, where the causality runs unidirectionally from exports to productivity in the long run. Unlike other studies, we have not

\footnotetext{
${ }^{15}$ Available upon request for both models.
} 
found a bidirectional causality relation, as exports became exogenous in our analysis. Additionally, not only exports but also investment has a positive effect on productivity. This result is interesting because it shows that both exports and capital accumulation play a central role in the long-run dynamics of productivity in China. Thus, our results are also consistent with the existence of an investment-led productivity growth effect. The second long-run relationship shows that investment and $R \& D$ expenditure are cointegrated. An interesting result derived from this analysis is that $R \& D$ expenditure affects investment directly and positively with a moderate coefficient, and that it has an indirect effect on productivity through investment.

Table 3 represents the dynamics of the short-run structure where the over-identifying restrictions based on the LR test are accepted with $\chi \square^{2}(23)=31.669(0.1072)$.

Table 3. Short-run Identification

\begin{tabular}{|c|c|c|c|c|c|c|c|}
\hline \multicolumn{4}{|c|}{ Model 1: Labor productivity model } & \multicolumn{4}{|c|}{ Model 2: GDP model } \\
\hline \multirow{3}{*}{$\Delta \operatorname{lprod}_{\mathrm{t}-1}$} & Alprod & $\Delta l i n v$ & Dlrer & \multirow{3}{*}{$\Delta \operatorname{lgdp} \mathrm{t}-1_{1}$} & $\Delta \lg d p$ & $\Delta l i n v$ & Dlrer \\
\hline & 0.34 & 1.14 & - & & - & - & 0.64 \\
\hline & $(4.79)$ & $(7.26)$ & - & & - & - & $(3.83)$ \\
\hline \multirow[t]{2}{*}{$\Delta \operatorname{lgdpusa}$} & 0.36 & - & -0.65 & \multirow[t]{2}{*}{$\Delta \operatorname{linv}_{\mathrm{t}-1}$} & 0.21 & 0.41 & -0.23 \\
\hline & $(2.74)$ & - & $(-3.05)$ & & $(7.31)$ & $(5.33)$ & $(-3.18)$ \\
\hline \multirow{2}{*}{$\Delta$ gdpusa $_{\mathrm{t}-1}$} & 0.50 & 1.05 & & \multirow{2}{*}{$\Delta \operatorname{lrer}_{\mathrm{t}-1}$} & -0.25 & -0.48 & - \\
\hline & $(3.66)$ & (2.99) & & & $(-2.80)$ & $(-2.14)$ & - \\
\hline \multirow[t]{2}{*}{$\Delta \operatorname{lexp}$} & - & -0.18 & 0.13 & \multirow[t]{2}{*}{$\Delta \operatorname{lexp}$} & 0.07 & - & - \\
\hline & - & $(-3.32)$ & (4.55) & & (4.08) & - & - \\
\hline \multirow[t]{2}{*}{$\Delta \operatorname{lexp}_{\mathrm{t}-1}$} & - & - & -0.09 & \multirow[t]{2}{*}{$\Delta$ gdpusa } & - & -0.83 & - \\
\hline & - & - & $(-2.80)$ & & - & $(-2.78)$ & - \\
\hline \multirow[t]{2}{*}{$\Delta \operatorname{lrd}$} & 0.12 & 0.40 & - & \multirow[t]{2}{*}{$\Delta$ gdpusa $_{\mathrm{t}-1}$} & 0.54 & 0.94 & - \\
\hline & (5.64) & (7.95) & - & & $(4.00)$ & $(2.76)$ & - \\
\hline \multirow{2}{*}{$\Delta \operatorname{lrd}_{\mathrm{t}-1}$} & 0.07 & - & - & \multirow[t]{2}{*}{$\Delta \operatorname{lrd}$} & 0.15 & 0.35 & - \\
\hline & $(2.95)$ & - & - & & $(7.29)$ & $(6.92)$ & - \\
\hline \multirow[t]{2}{*}{ Constant } & -0.95 & 0.84 & 0.43 & \multirow[t]{2}{*}{ Constant } & 2.29 & 3.67 & 1.03 \\
\hline & $(-3.58)$ & (1.32) & $(2.35)$ & & (7.87) & $(5.00)$ & (4.79) \\
\hline \multirow[t]{2}{*}{$\Delta \mathrm{D}_{\mathrm{s} 94}$} & 0.12 & 0.20 & - & \multirow[t]{2}{*}{$\Delta \mathrm{D}_{\mathrm{s} 94}$} & - & - & 0.16 \\
\hline & (6.18) & (3.95) & - & & - & - & $(-5.84)$ \\
\hline \multirow[t]{2}{*}{$\Delta \mathrm{D}_{\mathrm{s} 78}$} & -0.03 & -0.14 & - & \multirow[t]{2}{*}{$\Delta \mathrm{D}_{\mathrm{s} 78}$} & - & - & -0.08 \\
\hline & $(-2.31)$ & $(-3.23)$ & - & & - & - & $(-3.39)$ \\
\hline \multirow[t]{2}{*}{$\Delta \mathrm{D}_{\mathrm{s} 78 \mathrm{t}-1}$} & -0.03 & -0.13 & - & \multirow[t]{2}{*}{$\Delta \mathrm{D}_{\mathrm{s} 78 \mathrm{t}-1}$} & -0.05 & -0.11 & - \\
\hline & $(-2.33)$ & $(-3.05)$ & - & & $(-3.07)$ & (2.64) & - \\
\hline \multirow[t]{2}{*}{$\operatorname{dum}_{89 p}$} & -0.04 & -0.27 & - & \multirow[t]{2}{*}{$\operatorname{dum}_{89 p}$} & -0.04 & -0.27 & - \\
\hline & $(-2.46)$ & $(-6.29)$ & - & & $(-2.30)$ & $(-6.27)$ & - \\
\hline \multirow[t]{2}{*}{$\mathrm{ecm}_{1(\mathrm{t}-1)}$} & -0.35 & -0.31 & - & \multirow[t]{2}{*}{$\mathrm{ecm}_{1(\mathrm{t}-1)}$} & -0.61 & -0.65 & - \\
\hline & $(-7.11)$ & $(-2.54)$ & - & & $(-7.65)$ & $(-3.27)$ & - \\
\hline \multirow[t]{2}{*}{$\mathrm{ecm}_{2(\mathrm{t}-1)}$} & -0.27 & -0.81 & -0.13 & \multirow[t]{2}{*}{$\mathrm{ecm}_{2(\mathrm{t}-1)}$} & -0.39 & -1.02 & -0.52 \\
\hline & $(-5.18)$ & $(-6.52)$ & $(-2.17)$ & & $(-5.19)$ & $(-5.09)$ & $(-4.77)$ \\
\hline
\end{tabular}


Productivity adjusts toward equilibrium with the export- and investment-led productivity relationship $\left(e c m_{1}\right)$ and the investment vector $\left(e c m_{2}\right)$. The alpha coefficients show the speed and direction toward equilibrium. In the labor productivity equation, it can be observed that the adjustment is relatively slow and productivity adjusts toward equilibrium approximately every two years and is probably associated with the continuous transformations in the Chinese economy within the period considered. Additionally, in the dynamics of the model we can observe that R\&D expenditure has a positive effect on the productivity equation in the short run. This indicates that not only the transfer and absorption of foreign technology through the generation of spillovers from exports favor efficiency and productivity, but that efforts in innovation play a relevant role in improving productivity in the Chinese economy. Moreover, foreign demand, measured by the US activity level, shows a procyclical performance, which favors the growth of productivity. Finally, the productivity lag itself has a positive effect on the productivity equation.

Investment also adjusts toward equilibrium with both vectors found in the long run. The alpha coefficients in the investment equation show that, similarly to the previous equation, adjustment with the first vector is relatively slow. Adjustment toward equilibrium with the second cointegrated vector (investment vector), however, is reasonably fast. Moreover, in its own equation, investment shows a minor overreaction, given the negative coefficient in $e c m_{1}$. However, it is compensated by the higher negative value in $\mathrm{ecm}_{2}$, and as a consequence this long-run relationship adjusts toward equilibrium. An interesting result in the short run is that investment accelerates as productivity increases, since a positive productivity shock probably attracts investment through the expectations of obtaining future returns. In addition, we observe that foreign demand and R\&D expenditure both favor increased investment. Nevertheless, one unexpected result we found is that exports would have a transitory negative effect on the investment equation. 
Finally, the third equation reveals that the real exchange rate is appreciated when investment is over the steady state $(e \mathrm{Cm})$. This result can probably be explained by the fact that when investment is over its value in the long run, it causes an inflationary effect owing to an increase in the aggregate demand, and the consequent appreciation of the real exchange rate.

\section{Output Model}

Similarly to the previous model, our starting point is the output model which contains the following variables: Chinese activity level (GDP), exports, investment, real exchange rate, R\&D expenditure, and the US activity level.

Once again, either the exogeneity or the endogeneity of the variables considered in the simple model is analyzed under the assumption that the US activity level is weakly exogenous. Like the productivity model, the exogeneity test shows us that exports are exogenous with a $p$-value of 0.27 . Therefore, by following the same sequence as the previous model specification, we also found that $\mathrm{R} \& \mathrm{D}$ expenditure is exogenous with a $p$-value of 0.09 . Thus, at the end of this process, our model contains three endogenous variables (China's GDP, investment, and real exchange rate) and three exogenous variables (exports, R\&D expenditure, and the US activity level). Finally, determining the number of lags in accordance with the criterion of Hannan and Quinn shows that two lags are enough to capture the dynamic effects and to avoid autocorrelation problems. Indeed, we also made a battery of misspecification tests for the residuals of this model, where neither autocorrelation nor normality problems were found.

In Table 4 it can be seen that both the null hypotheses of the absence of cointegration and the existence of one cointegration vector are clearly rejected. In our model, therefore, we accepted the null hypothesis of the existence of two long-run relationships $(r=2)$ and a common trend, where both $p$-values accept the null hypothesis, and the inverse root of the characteristic polynomial for 
$r=2$ is 0.78 , i.e. less than unity. This shows that our relationships are stationary and adjust toward equilibrium.

Table 4. Determination of the Rank Test in the Output model

\begin{tabular}{cccccccc}
\hline $\mathrm{p}-\mathrm{r}$ & $\mathrm{r}$ & Eigenvalue & Trace & Trace* & $95 \%$ & $\mathrm{p}$-value & $\mathrm{p}$-value* \\
\hline 3 & 0 & 0.76 & 116.82 & 99.43 & 76.16 & 0.000 & 0.000 \\
2 & 1 & 0.59 & 58.39 & 50.49 & 49.62 & 0.006 & 0.041 \\
1 & 2 & 0.40 & 20.95 & 17.02 & 25.60 & $\mathbf{0 . 1 6 6}$ & $\mathbf{0 . 3 7 5}$ \\
\hline
\end{tabular}

Note: $\left(^{*}\right)$ corresponds to the trace test with Bartlett's correction. The asymptotic distributions have been simulated for the current deterministic specifications

In the model we selected, the following cointegration vectors can be found to be expressed as error correction mechanisms (t-values in brackets):

$$
\begin{aligned}
& e c m_{1}=\lg d p-0.39 / \text { inv }-0.88 / \mathrm{rer}-0.10 / \exp -0.25 D_{s 94}-0.15 D_{s 78} \\
& {[-9.98] \quad[-6.20] \quad[-3.31] \quad[-6.43] \quad[-4.32]} \\
& e c m_{2}=l i n v-0.28 / r d+0.23 D_{s 78}-0.09 t \\
& {[-5.67] \quad[-7.68] \quad[-29.09]}
\end{aligned}
$$

The coefficients associated with the variables in both relations are statistically significant and show the expected signs. The restrictions imposed in both cointegrating vectors are accepted with a $p$-value of 0.425 . The coefficients of the adjustment toward equilibrium are also statistically significant and negative, and show a value of $-0.42(-7.21)$ and $-0.82(-6.47)$ for the first and second relationship (ecm and $e c m_{2}$ ), respectively. Finally, the reduced-form model is stable in the forward and backward analysis.

The long-run model for output is very similar to the model of productivity that we have seen. The first relationship corresponding to (4) shows a positive relationship among China's output, investment, real exchange rate, and exports. Our findings are consistent with the export-led growth hypothesis, which predicts the existence of a positive relationship between the level of domestic 
activity and exports, where the direction of the causality runs unidirectionally from exports to the GDP in the long run. Furthermore, the positive effect of investment on output in the long run emphasized by the literature also appears in this relationship. Our findings are therefore consistent with Yusuf (1994), who found that capital accumulation is one of the most important factors in the economic growth process in China.

As mentioned above, we included the real exchange rate as a proxy variable to take competitiveness into account in the analysis, given that a close relationship is maintained between the real exchange rate and trade, and even investment. On comparing it with the previous productivity model, however, it can be observed that the real exchange rate positively affects output in the long run. As stated earlier, this result is in line with the findings of Rodrik (2008), Gala (2008), and Levi-Yeyati and Sturzenegger (2007), among others.

The effects of R\&D expenditure on investment can be observed in the second relationship (5). This result is interesting in the sense that investment is affected by the innovating effort of the Chinese economy in both the models analyzed, since it allows investment to increase and stimulates the accumulation of physical capital, which also favors economic growth.

Table 3 shows the dynamic structure of the output model, where the over-identifying restrictions based on the LR test are accepted and the test is distributed as $\chi^{2}(25)=32.606(0.1412)$.

The Chinese activity level adjusts toward equilibrium with the two cointegrated vectors that were found. In contrast to the previous model, the alpha coefficients in this model show a reasonably fast adjustment. Output level adjusts toward equilibrium with the first relation approximately every year and a half. In the dynamic model, the US activity level displays a procyclical performance which is similar to that of the productivity model. Furthermore, R\&D expenditure, investment and exports positively affect output in the short run. However, the real exchange rate shows a transitory negative effect. 
Like the productivity model, investment adjusts toward equilibrium with the two vectors found. In this equation, it can be observed how both vectors show a relatively fast speed of adjustment. Investment is error-correcting with the second long-run relation and adjusts toward equilibrium approximately every year. Similarly to the productivity model, the investment equation overreacts with the first relation (productivity vector), but is also compensated by the negative coefficient in ecm. $\mathrm{R} \& \mathrm{D}$ expenditure has directly favored increased investment in China. The dynamics of this model show that investment, $R \& D$ expenditure, and the US activity level have a positive effect on the investment equation. Once again, however, the real exchange rate has a transitory negative effect in the short run.

Finally, similar to the previous model, the real exchange rate adjusts toward equilibrium with the second cointegrated vector that was found $(e \mathrm{em})$. When investment is over its value in the long run, it causes an appreciation of the real exchange rate, and the alpha coefficient shows a reasonable speed of adjustment toward equilibrium of approximately a year and a half.

\section{Conclusions}

In the present paper, we have analyzed whether the rapid process of economic growth in China since the 1960s, especially in labor productivity and output, can be mainly explained by an investment-led growth effect or, conversely, we are in the presence of an export-led growth effect. Moreover, we also investigate the empirical relationship between the real exchange rate and output, due to the fact that previous evidence suggests it has been used as an additional economic policy to stimulate growth. Unlike other studies, new relevant factors such as R\&D expenditure, the real exchange rate, and foreign output were also included in our analysis. Thus, we emphasized the complementarities between capital accumulation and innovation, combined with openness, as the most important channels in which to stimulate economic activity.

Our empirical evidence shows that both an export-led growth effect and an investment-led 
growth effect are relevant in the Chinese economy. And this result remains whether we analyze the long-term dynamics of output or productivity. In both models a positive relationship is found among labor productivity or output, exports and investment in the long run. Additionally, our findings show that exports exogenously drive output and productivity in the long run. Furthermore, we found that R\&D encourages investment with a moderate coefficient in the long run. In contrast to the productivity model, we found that the real exchange rate played an important role in determining the output level. Moreover, bearing in mind the continuous process of reforms in China during the period under study, these findings can only be found if structural changes in 1978 and 1994 are considered. In accordance with the results found in this paper, everything seems to indicate that there are additional factors that account for China's growth other than exports, the export-led growth hypothesis being only part of the explanation in this process.

\section{References}

Aschauer, David Alan, 1989, "Is public expenditure productive?," Journal of Monetary Economics, Vol. 23, No. 2, pp. 177-200.

Baldwin, Richard and Elena Seghezza, 1996, "Trade-induced investment-led growth," NBER Working Paper No. 5582, National Bureau of Economic Research, Cambridge, MA.

Blomstrom, Magnus, Lipsey, Robert E, and Zejan, Mario, 1996, "Is fixed investment the key to economic growth?," The Quarterly Journal of Economics, Vol. 111, No. 1, pp. 269-76.

Bond, Steve, Asli Leblebicioglu, and Fabio Schiantarelli, 2004, "Capital accumulation and growth: A new look at the empirical evidence," Economics Department, Boston College Working Paper, No. 591.

Caruso, Massimo, 2002, "Procyclical productivity and output growth in China: An econometric analysis," Open economies review, Vol. 13, No. 3, pp. 251-74

Chen, Jie, Feng Guo and Aiyong Zhu, 2009, "Housing wealth, financial wealth and consumption in China," China \& World Economy, Vol. 17, No. 3, pp. 57-14.

Chow, Gregory, 1993, "Capital formation and economic growth in China," The Quarterly Journal of Economics, Vol. 108, No. 3, pp. 809-42.

De Long, J. Bradford and Lawrence H. Summers, 1992, "Equipment investment and economic growth: How strong is the nexus?," Brookings Papers on Economic activity, Vol. 1992, No. 2, pp. 157-211

Esfahani, Hadi Salehi, 1991, "Exports, imports, and economic growth in semi-industrialized countries," Journal of Development Economics, Vol. 35, No. 1, pp. 93-116.

Feder, Gershon, 1983, "On exports and economic growth," Journal of Development Economics, Vol. 12, No. $1-2$, pp. 59-73

Frankel, Jeffrey A.,and David Romer, 1999, "Does trade cause growth?" The American Economic Review, Vol. 89, No. 3, pp. 379-94 
Gala, Paulo. 2008, "Real exchange rate levels and economic development: Theoretical analysis and empirical evidence," Cambridge Journal of Economics, Vol. 32, No.2, pp. 273-288

Grossman, Gene .M, and Elhanan Helpman, 1991, Innovation and growth in the global economy, Cambridge, Massachusetts: The MIT Press.

Helpman, Elhanan and Paul Krugman, 1985, Market structure and foreign trade, Cambridge, Massachusetts: The MIT Press.

Helpman, Elhanan, 1988, "Growth technological progress and trade," Empirica Austrian Economic Papers, Vol. 5, No. 1, pp. 5-25

Hendry, David F.; and Grayham E. Mizon, 1993, Evaluating econometric models by encompassing the VAR. In PC.B. Philips (ed).Models, methods and application of econometrics: Essays in Honor of A.R. Bergstron. The MIT Press: Cambridge Mass.

Howitt, Peter, 2000, "Endogenous growth and cross-country income differences," American Economic Review, Vol. 90, No. 4, pp. 829-846

Howitt, Peter, and Philippe Aghion, 1998, "Capital accumulation and innovation as complementary factors in long-run growth," Journal of Economic Growth, Vol. 3, No. 2, pp. 111-130

Hsiao, Frank S.T, and Mei-Chu Hsiao, 2006, "FDI, exports, and GDP in East and Southeast Asia-Panel data versus time-series causality analyses," Journal of Asian Economics, Vol. 17, No. 6, pp. 1082-1106

Hu, Zuliu, and Mohsin S. Khan, 1996, "Why is China growing so fast?," IMF Working Papers, No. 96/75.

Jin, Jang C, 2004, "On the relationship between openness and growth in China: Evidence from provincial time series data," The World Economy, Vol. 27, No. 10, pp. 1571-1582

Johansen, Soren, and Katarina, Juselius 1994, "Identification of the long-run and the short-run structure. An application to the ISLM model," Journal of Econometrics, Vol. 63, No. 1, pp. 7-36

Johansen, Soren, 1995, Likelihood-Based inference in cointegrated vector auto-regressive models. Advance Texts in Econometrics. Oxford University Press: Oxford

Jones, Charles, I. 1995, "Time series Tests of endogenous growth models," The Quarterly Journal of Economics, Vol. 110, No. 2, pp. 495-525

Juselius, Katarina, 2007, The cointegrated VAR model: Econometric methodology and macroeconomics applications. Oxford University Press. Oxford.

Krugman, Paul, 1994, “The myth of Asia's miracle," Foreign Affairs, Vol. 73, No. 6, pp. 62-78

Kwan, Andy, Yanrui Wu and Junxi Zhang, 1999, "Fixed investment and economic growth in China," Economics of planning, Vol. 32, No. 1, pp. 67-79.

Levy-Yeyati, E. and F. Sturzenegger, 2007, "Fear of appreciation," World Bank Policy Research Working Paper No. 4387, Washington, DC, 1 November.

Lin, Shuanglin, 1999, "Export expansion and economic growth : Evidence from Chinese provinces," Pacific Economic Review, Vol. 4, No. 1, pp. 65-77.

Liu, Xiaming, Haiyan Song and Peter Romilly, 1997, "An empirical investigation of the causal relationship between openness and economic growth in China," Applied Economics, Vol. 29, No. 12, pp. 1679-86.

Liu, Xiaohui, Peter Burridge, P. J. N. Sinclair, 2002, "Relationships between economic growth, foreign direct investment and trade: evidence from China," Applied Economics, Vol. 34, No. 11, pp. 1433-1440.

Lopez, Ricardo A., 2005, "Trade and growth: Reconciling the macroeconomic and microeconomic Evidence," Journal of Economic Surveys, Vol. 19, No. 4, pp. 623-648

Marin, Dalia, 1992, "Is the export-led growth hypothesis valid for industrialized countries?," Review of Economics and Statistics, Vol. 74, No. 4, pp. 678-88

Melitz, Marc J., 2003, "The Impact of trade on intra-industry reallocations and aggregate industry productivity," Econometrica, Vol. 71, No. 6, pp. 1695-1725

Nielsen, Heino. 2004, "Cointegration analysis in the presence of outliers," Econometrics Journal, Vol. 7, No. 1, pp. 249-271 
Noguer, Marta, and Marc Siscart, 2005, "Trade raises income: a precise and robust result," Journal of International Economics, Vol. 65, No. 2, pp. 447-460

Pack, Howard and John Page, 1994, "Accumulation, exports and growth in the high-performing Asian economies," Carnegie-Rochester Conferences series on public policy, Vol. 40, No. 1, pp. 199-235

Qin, Duo, Marie Anne Cagas, Pilipinas Quising, and Xin-Hua He, 2005, "How much does investment drive economic growth in China?" Queen Mary University of London, Department of economics, working paper No. 545.

Rebelo, Sergio, 1991, "Long-Run Policy Analysis and Long-Run Growth," Journal of Political Economy, Vol. 99, No. 3, pp. 500-521.

Rodriguez, Francisco; and Dani Rodrik, 2001, Trade policy and economic growth: A skeptic's guide to the cross-national evidence in B.S. Bernake and K. Rogoff (eds.) NBER Macroeconomics Annual 2000, The MIT press Cambridge.

Rodrik, Dani, 1995, "Getting interventions right: how South Korea and Taiwan grew rich," Economic Policy, Vol. 10, No.20, pp. 53-107.

Rodrik, Dani, 2006, "What's So Special about China's Exports?," China \& World Economy, Vol. 14, No.5, pp. 1-19.

Rodrik, Dani, 2008, "The real exchange rate and economic growth," Brookings Papers on Economic Activity Fall, 2008. Available at www.brookings.edu/economics/bpea/bpea.aspx.

Romer, Paul, 1986, "Increasing returns and long-run growth," The Journal of Economics Perspectives, Vol. 8, No. 5, pp. 3-22

Shan, Jordan and Fiona Sun, 1998, "On the export-led growth hypothesis: the econometric evidence from China," Applied Economics, Vol. 30, No. 8, pp. 1055-1065.

Yao, Shujie, 2006, "On economic growth, FDI and exports in China," Applied Economics, Vol. 38, No.3, pp. $339-51$.

Young, Alwyn, 1992, Tale of Two Cities: Factor Accumulation and Technical Change in Hong Kong and Singapore, NBER Macroeconomics Annual. The MIT Press.

Yu, Qiao, 1998, "Capital investment, international trade and economic growth in China: Evidence in the 1980-90s," China Economic Review, Vol. 9, No. 1, pp. 73-84.

Yusuf, Shahid, 1994, "China's macroeconomic performance and management during transition," The Journal of Economic Perspectives, Vol. 18, No. 2, pp. 71-92. 